\title{
Correlation Between Direct Contact Status with Diphteria in Blitar
}

\author{
Ana Nur Filiya ${ }^{1}$, Novy Ardyanti Putri² \\ Institute of Health Sciences Bhakti Wiyata Kediri, Indonesia \\ University of Airlangga, Indonesia \\ ana.nur.filia@iik.ac.id
}

\begin{abstract}
Diphtheria is a contagion deadly disease which case increases year-by-year. Objective: To know the correlation of direct contact with diphteria patient towards diphteria in Blitar in 2016. This research method uses Observational-analytic study by using case control design. Sample in case group were 31 people of diphteria patients and 31 people of control group which is not a diphteria patients. Direct contact as Independent variable. Data were analyzed by Mc Nemar. The results showed $p$ value is 0.21 . Direct contact haven't associated with diphteria. Further research can use more detailed questionnaire to know direct contact status properly
\end{abstract}

Keywords: Blitar, diphteriae, Direct Contact 


\section{STRADA Jurnal Ilmiah Kesehatan}

DOI: $10.30994 /$ sjik.v8i2.185

ISSN: 2252-3847 (print); 2614-350X (online)

Vol.8 No.2. November 2019. Page.97-100

\section{BACKGROUND}

Diphtheriae is a deadly infectious disease that attacks the upper respiratory tract caused by the Corynebacterium diphtheriae bacteria. Diphtheria cases in Blitar Regency tend to increase every year. The number of cases in 2011 were 15 cases, in 2012 there were 23 cases, in 2013 as many as 17 cases, in 2014 there were 21 cases, in 2015 there were 44 cases, and in 2016 as many as 48 cases.

Diphtheria transmission occurs through contact with the patients and with careers when the patients or careers cough, sneeze, and speak (Mandal et al, 2006). Corynebacterium diphtheriae bacteria enter the nose or mouth and then grow on the upper respiratory tract mucosa, especially in the tonsils, and sometimes in the skin, genital or conjunctival regions. Bacteria then produce toxins that are absorbed by the body through mucous cell membranes, cause inflammation and damage to the epithelium, and are followed by necrosis (Harrison, 2008).

Before vaccination, diphtheria is a disease that often causes death. However, since the implementation of the DPT immunization program, the number of diphtheria cases has decreased significantly. The mortality rate of diphtheria ranges from 5-10\%, but in Indonesia the average reaches 15\% (Widoyono, 2005). From 1980-2010, there were 55 cases of diphtheria in the United States reported to the Centers for Disease Control and Prevention (CDC) with 77\% of cases of diphtheria attacking children aged 15 years or more. 4 of the 5 fatal cases of which occurred in children who did not get the vaccine. The fifth fatal case was a resident who returned from a country with endemic diseases (CDC, 2011). The number of diphtheria cases in Indonesia still tends to be high where in 2009 there were 189 cases, in 2010 there were 432 cases, in 2011 there were 806 cases, and in 2012 there were 1,194 cases. In 2013 and 2014, the number of diphtheria cases decreased, namely in 2013 as many as 778 cases, and in 2014 there were 396 cases. Of the 22 provinces that reported cases of diphtheria, the highest cases in East Java were 295 cases, which meant East Java contributed $74 \%$ of the total cases (Ministry of Health, 2014).

Risk factors for an illness can be more than one, let alone an infectious disease that can potentially lead to outbreaks. In a diphtheria outbreak there are known several risk factors, for example the immunization status of an incomplete person is not even immunized at all, low nutritional status, related to the cold chain vaccine namely refrigerator temperature $>8$ $\varnothing{ }^{\text {a }} \mathrm{C}$, high population mobility, absence of village midwives to provide services immunization, posyandu is not open routinely, and so on. So the most important risk factors must be found (East Java Health Office, 2011). Therefore, research needs to be done to determine the factors associated with the incidence of diphtheria in Blitar District. With the knowledge of the factors related to diphtheria, the Blitar District Health Office and Puskesmas in Blitar District are expected to be able to intervene appropriately so that the number of diphtheria cases in Blitar Regency can be reduced.

\section{OBJECTIVE}

This study aimed to describe Correlation Between Direct Contact Status with Diphteria in Blitar.

\section{METHODS}

This research is an observational analytic with case control design in Blitar at April to Nopember 2018. The 47 cases of the subjects were the patient who suspect diphteriae in Blitar District Health Office in 2016 that taken by total sampling technique. The 47 control 


\title{
STRADA Jurnal Ilmiah Kesehatan
}

DOI: $10.30994 /$ sjik.v8i2.185

ISSN: 2252-3847 (print); 2614-350X (online)

Vol.8 No.2. November 2019. Page.97-100

were the people who had same characteristics in age, sex, and residence. The statistical test was the Mc Nemar test.

\section{RESULTS}

The results of bivariate analysis are presented in Figure 1. The results of the analysis show that the direct contact status with patients has a significant relationship with the incidence of diphtheria.

\section{Direct contact factor for Diptheriae incidence}

\author{
Kontrol a kasus
}

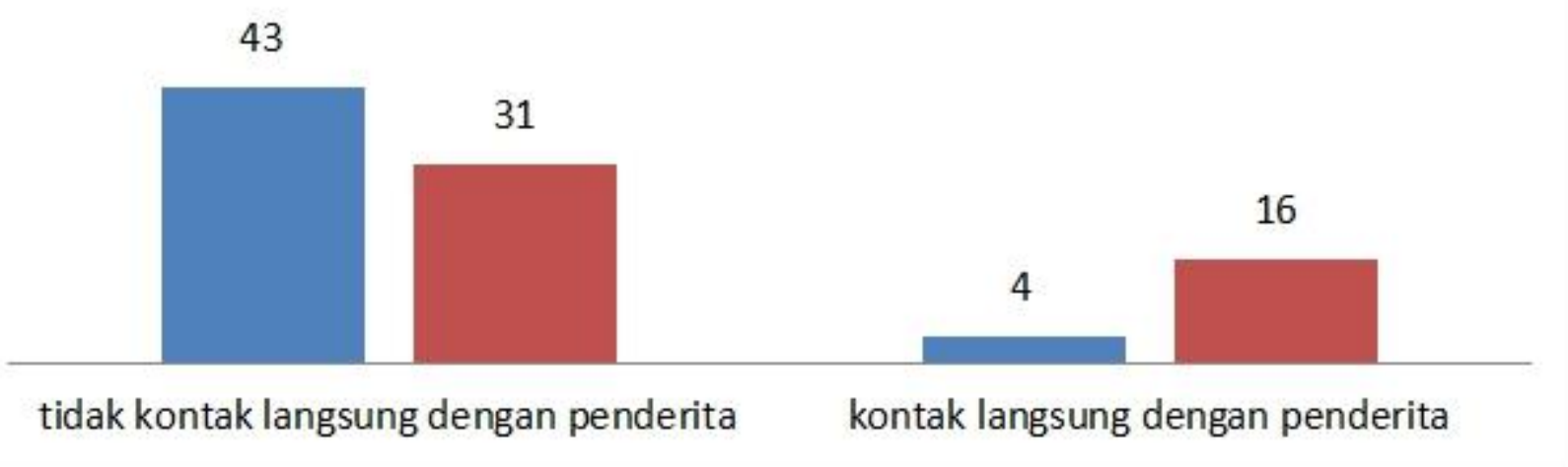

\section{Picture 1 Direct contact factor for diphteriae incidence}

Based on Figure 1, it was found that most diphtheria sufferers were 31 respondents (66\%) felt they never had direct contact with diphtheria sufferers before illness and 16 patients with diphtheria (34\%) felt they had direct contact with diphtheria sufferers. The control respondents, it was found that most of the 43 respondents $(91.5 \%)$ felt they never had direct contact with diphtheria sufferers and 4 respondents $(8.5 \%)$ knew that they had direct contact with diphtheria sufferers. The OR value is 2.75 which means that direct contact with patients is at 2.75 times the risk of diphtheria. The McNemar test p value is 0.001 which means there is a relationship between direct contact with the patient and the incidence of diphtheria.

\section{DISCUSSION}

Based on the results of statistical tests with McNemar's analysis, it was found that there was a relationship between the status of direct contact with patients and the incidence of diphtheria in Blitar District. The occurrence of diphtheria cases with direct contact with the patient caused by several things, the important thing is diphtheria is a deadly infectious disease that attacks the upper respiratory tract caused by the bacteria Corynebacterium diphtheria. This transmission is strongly supported by the condition of the body that is in a weak point so that it can easily contract diphtheria. 


\section{STRADA Jurnal Ilmiah Kesehatan}

DOI: $10.30994 /$ sjik.v8i2.185

ISSN: 2252-3847 (print); 2614-350X (online)

Vol.8 No.2. November 2019. Page.97-100

Transmission of diphtheria occurs through contact with patients and with careers when patients or careers cough, sneeze, and speak (Mandal et al, 2006). Corynebacterium diphtheriae bacteria enter the nose or mouth and then grow on the upper respiratory tract mucosa, especially in the tonsils, and sometimes in the skin, genital or conjunctival regions. Bacteria then produce toxins that are absorbed by the body through mucous cell membranes, cause inflammation and damage to the epithelium, and are followed by necrosis (Harrison, 2008).

\section{CONCLUSION}

According to the result of McNemar Test ( $p$ value=0,001) it means direct contact with patients affects the incidence of diphtheria in Blitar District in 2016. People who experience direct contact with patients with diphtheria will be at risk 3 times more likely to contract diphtheria $(\mathrm{OR}=2.75)$. Prevention of transmission can be done by increasing the body's immunity so that it is not easily infected with diphtheria-causing bacteria.

\section{REFERENCES}

CDC. (2011). Manual for the Surveillance of Vaccine-Preventable Diseases. Accessed: http://www.cdc.gov/vaccines/pubs/surv-manual/chpt01-dip.html.

The Health Department of The Republic of Indonesia. (2014). The Health of Indonesia Profile 2014. Jakarta: The Health Department of The Republic of Indonesia.

East Java Health Office. (2011). Guidelines for Prevention of Diphtheria Outbreaks in East Java. Surabaya: East Java Health Office.

Harrison. Principles of Internal Medicine. 17 ed. United States of America: McGraw-Hill Companies, Inc; 2008.

Kartono. (2007). House Environment and Incidence of Diphtheria in Tasikmalaya Regency and Garut Regency. National Public Health Journal. $2^{\text {nd }}$ Volume; $5^{\text {th }}$ Number.

Mandal, B., K., E., G., L., \& Wilkins., et all. Infectious Disease. Jakarta: Erlangga; 2006.

Widoyono. (2005). Tropical Epidemiology of Transmission and Eradication. Jakarta: Erlangga. 